\title{
Horacio Gutiérrez, Márcia Naxara e Maria Aparecida Lopes (Org.) Fronteiras: paisagens, personagens, identidades
}

Reinaldo Nishikawa USP

São Paulo: Olho d’Água, 2003, 300p.

Podemos entender as complexidades que a palavra "fronteira" pode conter se sua própria constituição se dá muitas vezes em termos historicamente mutantes, difusos, cercada de especificidades? Ou sucede o inverso: as fronteiras se formam por processos semelhantes em lugares diferentes? Essas questões são tratadas na coletânea Fronteiras: paisagens, personagens, identidades, organizada pelos professores Horácio Gutiérrez, Márcia Naxara e Maria Aparecida Lopes. Ao privilegiar as três Américas como escopo (portuguesa, espanhola e inglesa), os autores que compõem o livro demonstram que muitas imagens criadas no "Novo Mundo", em particular nas áreas de fronteira, esse espaço considerado demograficamente vazio e que acabou se tornando uma forma de legitimar a conquista, já não podem ser tomadas como corretas. A colonização entendida como um processo e as fronteiras como parte central desse processo são as linhas mestras seguidas no livro.

Os autores se comprometem a estudar as fronteiras, provando ser esta uma vertente importante para se entender os complexos mecanismos criados pela aproximação cultural dos diversos povos que conformam o mosaico americano. O estudo, composto por onze artigos, constitui um espaço de discussões para essa diversidade. O livro foi dividido em dois momentos que estão ligados entre si. A primeira parte é dedicada a pensar nas fronteiras como fundadoras de identidades, e segunda, a entender como essas fronteiras transformam as paisagens e os personagens tocados nesse processo.

Considerando que a maioria do território americano começou sua colonização pelo litoral, a expansão para o far west tornou-se um terreno propício para a criação de mitos embasados por ícones criados nessa expansão. As novas fronteiras trouxeram à tona personagens importantes nas suas conquis- 
tas. Temos o pioneer americano, o bandeirante brasileiro e o gaucho argentino, personagens que estão intrinsecamente ligados à expansão territorial. Entretanto, essa marcha implicou uma série de contrastes necessários para legitimar a presença do colonizador em terras estranhas. A presença do outro significava, em essência, um contato cultural, social, político e econômico de transformações irreversíveis. O livro em suas várias abordagens estuda esses impactos e procura entendê-los como um processo que engloba as Américas em suas diversas realidades.

A existência de "terras livres" nas Américas foi a justificativa encontrada por diversos colonizadores para legitimar as conquistas. Os artigos publicados neste livro nos mostram que a fronteira significa mobilidade e fluidez, e que não houve apenas uma única noção de fronteira na história das Américas, mas várias. Nos últimos séculos, o continente latino-americano possuía fronteiras diversas, as produtivas (a pecuária, a de metais preciosos), as fronteiras agrícolas (açúcar, café, algodão), e junto a elas, as fronteiras militares, de poder, bem como as lingüísticas e culturais. Essa pluralidade implica entender o longo processo de formação das fronteiras, das identidades criadas no transcurso do tempo e os personagens que se fixaram nessas fronteiras, e transformaram as paisagens existentes nesse caminho.

Os artigos que compõem a obra dão destaque também à importância dos povos "conquistados" e da influência mútua que os povos mantiveram com os colonizadores. Mesmo de uma forma desigual e arbitrária, os habitantes das Américas conseguiram impor certas práticas, certas influência e costumes, o que nos leva a um outro tópico.

Pensar no outro, naquele que faz parte do processo e que muitas vezes é esquecido tornou-se uma porta rica de entrada para o estudo da história e para os historiadores interessados em saber muito mais do que apenas compreender fronteiras como sinônimo de recorte espacial, ou como limites unicamente geográficos. $\mathrm{O}$ estudo das fronteiras demonstra que sua complexidade e suas implicações não podem passar despercebidas aos historiadores, uma vez que foram essas fronteiras que muitas vezes moldaram a identidade, as paisagens e a economia dos povos que aqui habitam. Para a compreensão de todos os meandros dessas fronteiras, os autores utilizaram, como seria necessário, variadas fontes de análises, que podem exemplificar-se no estudo de poemas, fotografias, pinturas, e até jornais, textos e relatos, prova de que a história não é estática e nem seus interlocutores.

É interessante perceber o quão ligados estão a fronteira e o sertão, ou o lugar considerado sertão enquanto uma construção histórica. As fronteiras 
vão ganhando especificidades e legitimidades dependendo de onde se origina tal conceito, e vários artigos que compõem o livro conseguem vislumbrar múltiplas gamas nas diversas regiões das Américas. O livro endossa a importância das transformações econômicas, políticas e sociais relacionadas ao momento em que as fronteiras são criadas e transformadas pela ação do homem.

Em alguns artigos publicados nos últimos tempos, os autores afirmam que a questão da fronteira não é tão discutida na historiografia latino-americana quanto na norte-americana, desconsiderando, segundo esses historiadores, o papel das fronteiras como formadoras das identidades criadas na América Latina. Talvez a publicação deste livro venha a dar resposta a essa afirmação, e demonstrar o interesse dos historiadores latino-americanos para a questão das fronteiras e suas implicações.

Ao fecharmos o livro, temos a impressão de que percorremos os quatro cantos das Américas (Estados Unidos, México, Caribe, Chile, Argentina, Uruguai e o Brasil) e conseguimos entender por que situações tão díspares quanto as colonizações portuguesa e inglesa, por exemplo, acabaram por percorrer o mesmo caminho em direção ao Oeste na tentativa de formar suas fronteiras. Os autores conseguiram mostrar que a conquista territorial nas Américas foi feita com sorrisos, e principalmente com muitas lágrimas. O livro, sem dúvida, vale um bom curso de História.

Resenha recebida em 03/2006. Aprovada em 06/2006 